\title{
Bioactivity of microencapsulated soursop seeds extract on Plutella xylostella
}

\author{
Bioatividade de extrato microencapsulado de sementes de graviola sobre Plutella xylostella
}

\author{
Ismael Barros Gomes ${ }^{\mathrm{I}}$ Roseane Cristina Predes Trindade $^{\mathrm{I}^{*}}$ Antônio Euzébio Goulart Sant'Ana ${ }^{\mathrm{II}}$ \\ Eurico Eduardo Pinto de Lemos Ir Irinaldo Diniz Basílio Júnior ${ }^{\mathrm{III}}$
}

\begin{abstract}
The aim of this study was to evaluate the bioactivity of microencapsulated extract from the soursop seeds, Annona muricata L. (Annonaceae), on diamondback moth, Plutella xylostela L. (Lepidoptera: Plutellidae). Microencapsulation was performed in a Mini Spray Dryer model B-290 using 50mL of ethanolic and hexanic extracts plus $150 \mathrm{~mL}$ of ethanol and $150 \mathrm{~mL}$ of ultrapure water, mixed with aerosil (first polymer) or arabic gum (second polymer). It was possible to microencapsulate the ethanolic extract of soursop seeds only by using the polymer arabic gum at $20 \%$. The microencapsulated extract caused significant acute toxicity $\left(L C_{50}=258 \mathrm{mg} \mathrm{L}^{-1}\right)$ and chronic effects, especially reduction of larval viability and increased larval stage. We concluded that the microencapsulation of the ethanolic extract of soursop seeds can be a viable alternative for controlling diamondback moth with possible gains for the environment.
\end{abstract}

Key words: diamondback moth, Annona muricata, biology, $L C_{50^{\circ}}$

RESUMO

O objetivo deste estudo foi avaliar a bioatividade do extrato microencapsulado das sementes de graviola, Annona muricata L. (Annonaceae), sobre a traça-dascrucíferas, Plutella xylostella L. (Lepidoptera: Plutellidae). A microencapsulação foi realizada em um Mini Spray Dryer modelo B-290 utilizando-se $50 \mathrm{~mL}$ dos extratos etanólico e hexânico mais $150 \mathrm{~mL}$ de álcool etílico e $150 \mathrm{~mL}$ de água ultrapurificada, misturado com aerosil (primeiro polimero) ou com goma arábica (segundo polímero). Só foi possível microencapsular o extrato etanólico de sementes de graviola com a utilização do polímero goma arábica a 20\%. O extrato microencapsulado causou significativa toxicidade aguda $\left(C L_{50}=258 \mathrm{mg} \mathrm{L}^{-1}\right)$ e efeitos crônicos, especialmente redução da viabilidade larval e aumento da duração do estágio larval.
Conclui-se que a microencapsulação do extrato etanólico da semente de graviola pode ser uma alternativa viável no controle da traça com possiveis ganhos para o meio ambiente.

Palavras-chave: traça-das-cruciferas, Annona muricata, biologia, $C L_{50}$

\section{INTRODUCTION}

Among the factors contributing to reduce brassica yield worldwide is diamondback moth - Plutella xylostella (L., 1758) (Lepidoptera: Plutellidae), a pest present in almost all producing regions and in all stages of the plant (TALEKAR \& SHELTON, 1993). Its control is difficult because of its fast capacity of migration, easy adaptation to the environment, high fecundity and short life cycle, which provides a rapid increase in its resistance to chemical insecticides (CASTELO BRANCO et al., 2001).

The use of synthetic insecticides has been the most used way to control this pest, which requires a high number of applications, leading a resistant to the major groups of insecticides which include organochlorines, organophosphates, carbamates and pyrethroids (FURLONG et al., 2013).

The search for new insecticides, including the use of plants as natural insecticides, is an open, broad and continuous field of research

\footnotetext{
ICentro de Ciências Agrárias, Universidade Federal de Alagoas (UFAL), BR 104N, s/n, 57100-000, Rio Largo, AL, Brasil. E-mail: roseane.predes@uol.com.br. "Corresponding author.

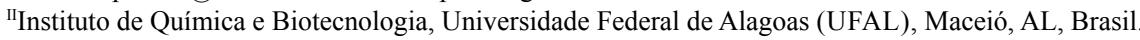

IIIEscola de Enfermagem e Farmácia, Universidade Federal de Alagoas (UFAL), Maceió, AL, Brasil.
} 
(SCHMALTZ et al., 2005). The diversity of substances present in the flora remains appealing in the area of insect control, taking into account that only a small portion of the plants was investigated with such a purpose.

Among the plants that have potential for pest control are some species of Annonaceae family, which have already been investigated (ISMAN \& SEFFRIN, 2014). One of these species is soursop (Annona muricata L.), that has shown some insecticidal, nematicidal and bactericidal effects. Its seeds are a promising source for manufacturing plant extracts, mainly because it is a byproduct of the industrialization process of soursop pulp (HERNANDÉZ \& ANGEL, 1997).

The $\boldsymbol{P}$. xylostella larvae showed $100 \%$ mortality when exposed for up to 12 days in the ethanol extract of $\boldsymbol{A}$. muricata $\left(5 \mathrm{mg} \mathrm{mL}^{-1}\right)$. The lower concentrations also affected the larval stage and its viability was reduced (TRINDADE et al., 2011).

Natural insecticides generally have short persistence in the environment after use and during storage (CLOYD, 2004). Therefore, it is necessary to develop formulations that could improve their viability and facilitate their application by farmers. Among the formulations used there is the emulsion that consists in a mixture of two immiscible fluids, by using agitation or addition of homogenizers (BAJPAI \& GIRI, 2002).

Another alternative is nanotechnology, process that has been applied mainly in the pharmaceutical and cosmetic industry to spread bioactive molecules more efficiently, facilitating penetration of these compounds into the human skin. For medicines is a widespread technique, but for cosmetics is a limited area because of its recent use (SCHMALTZ et al., 2005; BARIL et al., 2012). The application of nanotechnology in agricultural pest control is a very new approach of study, thus becoming a vast field to be explored (NEVES, 2008).

Thus, the microencapsulation process of soursop seed extracts could assure a more slow and controlled release of the active ingredients for the plants, thus enhancing its activity against pests and reducing the environmental impacts usually caused by synthetic products.

The aim of this study was to evaluate the bioactivity of microencapsulated extract from the soursop seeds, Annona muricata L. (Annonaceae) on the diamondback moth, Plutella xylostela L. (Lepidoptera: Plutellidae).

\section{MATERIALS AND METHODS}

Insect rearing

The initial population of $\boldsymbol{P}$. xylostella was derived of the Universidade Federal Rural de Pernambuco (UFRPE) and maintained at $26 \pm 2{ }^{\circ} \mathrm{C}, 60 \pm 10 \%$ relative air humidity and $12-$ hour photoperiod, according to the methodology established by MEDEIROS et al. (2003), and fed with leaves of cabbage, Brassica oleracea var. acephala DC. (Brassicaceae) cv. 'Georgia', produced in beds containing the commercial substrate Bioplant ${ }^{\mathrm{TM}}$ inside a green house. Experiments started from the third generation of insects in the laboratory.

Preparation of soursop seed extracts

Soursop seeds were obtained from the fresh waste of a processing fruit pulp company in Anadia, AL, Brazil, in 2012. Seeds were air-dried at $48^{\circ} \mathrm{C}$ for 48 hours, triturated in a forage grinding mill (mesh size $2.5 \mathrm{~mm}$ ) to yield a fine, uniform powder, and stored at $4 \pm 2^{\circ} \mathrm{C}$.

To prepare the hexanic extract, $2.3 \mathrm{~kg}$ of the seed powder were used with $5 \mathrm{~L}$ of hexane $\left[\mathrm{CH}_{3}\left(\mathrm{CH}_{2}\right) 4 \mathrm{CH}_{3}\right]$ in a percolator for a period of 72 hours. After that, the same seed powder was used for the ethanolic extraction using 4.6L of ethanol $\left(\mathrm{CH}_{3} \mathrm{CH}_{2} \mathrm{OH}\right)$ for three periods of 72 hours. Excess of solvents was removed under reduced pressure at $50^{\circ} \mathrm{C}$; and the crude residues were placed in desiccators to remove any remaining water and stored at $4 \pm 2^{\circ} \mathrm{C}$.

Microencapsulation

The microspheres were obtained by spray drying using Buchi ${ }^{\circledR}$ Mini Spray Dryer B -290 (Switzerland) with a nozzle of $1.0 \mathrm{~mm}$ and a parallel flow pattern at an inlet air temperature of $180^{\circ} \mathrm{C}$, a feed rate of $10 \mathrm{ml} \mathrm{min}^{-1}$ and aspirator at $100 \%$, representing an air flow of $35 \mathrm{~m}^{3} \mathrm{~h}^{-1}$. Two forms of microencapsulation were conducted: the first one by using $50 \mathrm{~mL}$ of organic extract plus $150 \mathrm{~mL}$ of absolute ethyl alcohol and $150 \mathrm{~mL}$ ultrapurified water, mixed and then added with aerosil (polymer) calculated from the weight of solid contained in $1 \mathrm{ml}$ of the extract. The solid weight of the extract was performed by placing $1 \mathrm{~mL}$ of the extract in an oven at $145^{\circ} \mathrm{C}$ for 4 hours and then weighed. The second one by performing the microencapsulation in the same way but replacing the aerosil for $20 \%$ gum arabic and mixed. 
Determination of $\mathrm{LC}_{50}$ and $\mathrm{LC}_{99}$ of microencapsulated soursop seed extracts and the effect of $\mathrm{LC}_{50}$ on Plutella xylostella biology

As in the microencapsulation process some losses in the active ingredients may occur, it was conducted a test to establish the $\mathrm{LC}_{50}$ and $\mathrm{LC}_{99}$ using the concentrations 0.0 (control), 100, 250, 500, 1.000 and $2.500 \mathrm{mg} \mathrm{L}^{-1}$ plus $10.000 \mathrm{mg} \mathrm{L}^{-1} \mathrm{DMSO}$ (Dimethyl sulphoxide) in distilled water.

Discs of $8 \mathrm{~cm}$ in diameter were cut from cabbage leaves including midrib and immersed separately for $30 \mathrm{~s}$ in the different solutions, and control discs were immersed only in $1 \%$ DMSO in distilled water. Discs were left to dry out at room temperature of $26 \pm 2{ }^{\circ} \mathrm{C}$ for 2 hours, after which they were placed in individual Petri dishes together with 12 newly hatched larvae. Dishes were sealed with PVC film and maintained at room temperature of $26 \pm 2^{\circ} \mathrm{C}, 60 \pm 10 \%$ relative air humidity and $12 \mathrm{~h}$ of photophase. As the cabbage discs became yellow, or were consumed by the larvae, they were replaced daily by newly treated discs. Larval mortality was evaluated on the third day of the experiment, when larvae left the leaf mines, and daily until the pupal stage.

In the insect biology experiment, to $\mathrm{LC}_{50}$ (258mg L $\mathrm{L}^{-1}$ ), when the larvae turned into pupae, they were individually placed in glass tubes until adult emergence and the duration and viability of larval, pupal stages and adults longevity were evaluated.

The experiment was carried out in a completely randomized design with six treatments and five replicates to determine the lethal concentrations of each extract. To determine the $\mathrm{LC}_{50}$ and $\mathrm{LC}_{99}$, it was used Probit analysis performed with the software SAS version 9.0 (SAS Institute, 2002). In the biology experiment, data were submitted to analysis of variance and means were compared by Tukey test, at $5 \%$ of probability. Data of the larval viability were transformed into $\sqrt{ } x+0.5$, with Assistat version 7.5 software (SILVA \& AZEVEDO, 2009).

\section{RESULTS AND DISCUSSION}

Microencapsulation

The first process of microencapsulation of the organic extracts using aerosil was considered not efficient as no powder (microcapsules containing the active ingredient) was formed. In the second process, when aerosil was replaced by gum arabic, a powder was formed containing the microcapsules $(25 \mu)$ only in the ethanolic seed extracts of soursop. The encapsulation efficiency was near 55\%.

SHAHIDI \& HAN (1993) suggest that encapsulation by spray-drying involves four stages: preparation of the dispersion or emulsion; homogenization dispersion; atomizing the emulsion, and dehydrating the atomized particles. The first stage consists of the formation of a fine stable emulsion of the active material solution. In this case, aerosil, which is an emulsion stabilizer (CORNEC, 1990), was not adequate.

However, the gum arabic, which is a product obtained by spontaneous drying of the exudates of Acacia senegal (L.) (Fabaceae), has wide application in the preparation of emulsions and suspensions, and is soluble in water (GABAS \& CAVALCANTI, 2003).

The microencapsulation of hexanic extract was not possible as no powder was formed and maintained its liquid form after two attempts. It is believed that the hexanic extract had the presence of oils (ONIMAWO, 2002), which hinder its microencapsulation.

Determination of $\mathrm{LC}_{50}$ and $\mathrm{LC}_{99}$ of microencapsulated ethanolic extract of soursop seeds to Plutella xylostella

The estimated lethal concentrations for microencapsulated ethanolic extract of soursop for $\mathrm{CL}_{50}$ (IC 95\%) were $258 \mathrm{mg} \mathrm{L}^{-1}\left(193-329 \mathrm{mg} \mathrm{L}^{-1}\right.$ ) and for $\mathrm{CL}_{99}$ (IC 95\%) were $3.081 \mathrm{mg} \mathrm{L}^{-1}$ (1.944$6.291 \mathrm{mg} \mathrm{L}^{-1)}$ with slope $( \pm$ EP) of $2.15( \pm 0.65)$ and $(\chi=17.5 ; \mathrm{df}=18)$.

Similar results of the biotoxic action of microencapsulated extracts were also observed by MARCOMINI (2009), when assessing nanoformulations of neem on Spodoptera frugiperda (J.E. Smith, 1798) (Lepidoptera: Noctuidae). The mortality rate was of $40-46 \%$ at concentrations of $0.64 \%$ (3.87mg AZ-A L ${ }^{-1}$ ), as well there was weight reduction of caterpillars. MARCOMINI (2009) showed that the microencapsulation preserved the active principle of the extract and that a higher concentration leads to a greater mortality of the insects, as seen in this study. KANIS et al. (2012) reported that microencapsulated extracts of Copaifera sp. (Leguminosae) showed reduced activity on the first day, but the insecticidal action remained above $40 \%$ for 17 days. The lower activity on the first day of the experiment could be explained by the slow release of the microencapsulated active ingredient, unlike the pure extract, where the active ingredient is released at once. In the present study, the mortality of larvae 
treated with microencapsulated extract was evenly distributed during the assessment, thus confirming the principle of slow release of the extract containing nano particles of the active principle.

JALALIZAND et al. (2013) studied the mortality effect of silver nano particles on adult twospotted spider mites, Tetranychus urticae (Koch, 1836) (Acari: Tetranychidae). They showed different effects on mites as they increased the concentrations at different time interval. GAVANJI et al. (2013) studied the comparative acaricidal efficacy of sulfur and nano sulphur and concluded that nano sulfur is a product effectively active against $\boldsymbol{T}$. urticae. Sulfur is an adulticide and nymphicide, but it was revealed that sulfur in nano scale shows a better inhibitory effect on mite populations.

Effect of $\mathrm{LC}_{50}$ of microencapsulated ethanolic extract of soursop seeds on Plutella xylostella biology

The larval duration $(\mathrm{df}=1, \mathrm{~F}=8.6512$, $\mathrm{P}=0.0087)$ and viability $(\mathrm{df}=1, \mathrm{~F}=14.2372$, $\mathrm{P}=0.0013$ ) were significantly different at $0.05 \%$ of probability by Tukey test. The other parameters pupal viability $(\mathrm{df}=1, \mathrm{~F}=1.9867, \mathrm{P}=0.1777)$ and duration $(\mathrm{df}=1, \mathrm{~F}=3.8954, \mathrm{P}=0.0658)$ and adult longevity $(\mathrm{df}=1, \mathrm{~F}=1.6855, \mathrm{P}=0.2124) \mathrm{did}$ not differ (Table 1).

The effect on the biology of insect was observed only in the larval stage. The larval viability was only $38.00 \%$ over a period of 8.91 days, well below the control that were $83.00 \%$ and 7.94 days, respectively (Table 1), showing that the microencapsulated treatment maintained for a longer period of time its ability to affect the development of $\boldsymbol{P}$. xylostella. In the same way, the development of Tuta absoluta (Meyrick, 1917) (Lepidoptera:
Gelechiidae) was also reported to be seriously affected by nanoformulation (NC40 powder) of aqueous solution of neem (FERREIRA et al., 2012). The treated larvae completed their development, in 16.1 days (control 12.2 days) and reduced the weight of the pupae to $23 \mathrm{mg}$ (control $27.9 \mathrm{mg}$ ).

MARCOMINI (2009) studying the performance of six microencapsulated nanoformulations of neem reported that larval and pupal viability of $\boldsymbol{S}$. frugiperda was not affected, but its larval duration, like in this research was significantly extended with a diet containing such nanoformulations.

The same technology has also been used to control other groups of insects like in the research of CARVALHO et al. (2015) who evaluated the efficacy of 19 nanoformulations of neem derivatives in controlling by systemic action nymphs of Bemisia tabaci (Genn., 1889) biotype B (Hemiptera: Aleyrodidae). Two nanoformulations (NC-2 and NCL5L6-1) were believed to cause similar mortality to the commercial neem oil. The systemic action of the oil and nanoformulations depends on environmental conditions in which they are enforced and nanoformulations can be bioactive for 30 days after application.

\section{CONCLUSIONS}

The use of gum arabic was effective in the microencapsulation process of soursop seed extract. The estimated lethal concentrations were $258 \mathrm{mg} \mathrm{L}^{-1}$ and $3.081 \mathrm{mg} \mathrm{L}^{-1}$ for the $\mathrm{CL}_{50}$ and $\mathrm{CL}_{99}$, respectively. The microencapsulated soursop seeds extract affect the larval duration and viability of $\boldsymbol{P}$. xylostella.

Table 1 - Mean \pm SE of larval and pupal viability and duration and adult longevity of Plutella xylostella treated with ethanolic seed extract of Annona muricata.

\begin{tabular}{llllcc}
\hline & Larval viability (\%) & Larval duration (days) & Pupal viability (\%) & Pupal duration (days) & Adult longevity (days) \\
\hline Control & $83.00 \pm 4.46 \mathrm{a}$ & $7.94 \pm 0.21 \mathrm{a}$ & $83.94 \pm 5.09 \mathrm{~ns}$ & $3.92 \pm 0.06 \mathrm{~ns}$ & $3.21 \pm 0.12 \mathrm{~ns}$ \\
Micro. & $38.00 \pm 7.56 \mathrm{~b}$ & $8.91 \pm 0.46 \mathrm{~b}$ & $68.54 \pm 8.76 \mathrm{~ns}$ & $5.27 \pm 0.23 \mathrm{~ns}$ & $2.76 \pm 0.32 \mathrm{~ns}$ \\
F & 14.2372 & 8.6512 & 1.9867 & 3.8954 & 1.6855 \\
P & 0.0013 & 0.0087 & 0.1777 & 0.0658 & 0.2124 \\
\hline
\end{tabular}

Means followed by the same letter in columns are not statistically different by Tukey test $(\mathrm{P} \leq 0.05)$.

ns $=$ Not significant.

$\mathrm{SE}=$ Standard error.

$\mathrm{F}=$ Test statistic $\mathrm{F}$.

$\mathrm{P}=$ value of $\mathrm{P}$. 


\section{ACKNOWLEDGEMENTS}

The first author is graterful to Coordenação de Aperfeiçoamento de Pessoal de Nível Superior (CAPES) which provided his scholarsship.

\section{REFERENCES}

BAJPAI, A. K.; GIRI, A. Swelling dynamics of a macromolecular hydrophilic network and evaluation of its potential for controlled release of agrochemicals. Reactive and Functional Polymers, v.53, p.125-141, 2002.

BARIL, M. B. et al. Nanotecnologia aplicada aos cosméticos. Visão Acadêmica, v.13, n.1, p.45-54, 2012.

CARVALHO, S.S. et al. Efeito inseticida sistêmico de nanoformulações à base de nim sobre Bemisia tabaci (Hemiptera: Aleyrodidae) biótipo B em tomateiro. Bragantia, v.74, n.3, p.298-306, 2015. Available from: <http://www.scielo.br/scielo php?pid=S0006-87052015000300298\&script $=$ sci_arttext $>$. Acessed: out 30, 2015. doi: 10.1590/1678-4499.0404.

CASTELO BRANCO, M. et al. Use of insecticides for controlling the South American Tomato Pinworm and the Diamondback Moth: a case study. Horticultura Brasileira, v. 19, n.1, p.60-63, 2001. Available from: $<$ http://www.scielo.br/scielo.php?script=sci_artte xt\&pid=S0102-05362001000100012 >. Acessed: jun 14, 2015. doi: 10.1590/S0102-05362001000100012.

CLOYD, R. A. Natural indeed: are natural insecticides safer and better than conventional insecticides? Illinois Pesticide Review, v.17, n.3, p.1-3, 2004.

CORNEC, M. Aérosil: um adjuvant effi cace pour lês formes sèches, liquids et pâteuses. STP Pharma Sciences, v.6, p.110-112, 1990.

FERREIRA, F. T. R. et al. Bioactivity of neem nanoformulations on tomato pinworm. Ciência Rural, v.42, n.8, p.1347-1353, 2012.

FURLONG, M. J. et al. Diamondback moth ecology and management: problems, progress, and prospects. Annual Review of Entomology, v.58, p.517-541, 2013.

GABAS, V. G. S.; CAVALCANTI, O.A. Influência da adição da goma arábica em filmes isolados de polímero acrílico. Estudo das propriedades de intumescimento e de permeabilidade. Revista Brasileira de Ciências Farmacêuticas, v.39, n.4, p.441-448, 2003.

GAVANJI, S. et al. Comparative acaricidal efficacy of sulfur and nano sulfur against Tetranychus urticae. International Journal of Scientific Research in Inventions and New Ideas, v.1, n.2, p.23-28, 2013.

HERNANDÉZ, C. R.; ANGEL, D.N. Anonaceas con propiedades insecticidas. In: SÃO JOSÉ, A.R. et al. Anonáceas produção e mercado (pinha, graviola, atemóia e cherimólia). Vitória da Conquista: Universidade Estadual do Sudoeste da Bahia,1997. p.229-239.

ISMAN, M. B.; SEFFRIN, R. Natural insecticides from the Annonaceae: a unique example for developing biopesticides. In: SINGH, D. (Ed.). Advances in plant biopesticides. Amsterdam: Springer, 2014. V. 15, Chap. 2, p. 21-33, 2014.

JALALIZAND, A. et al. The effect of Silver nanoparticles on Tetranychus urticae. International Journal of Agriculture and Crop Sciences, v.5, n.8, p.820-827, 2013.

KANIS, L. A. et al. Larvacidal activity of Copaifera sp. (Leguminosae) oleoresin microcapsules against Aedes aegypti (Diptera: Culicidae) larvae. Parasitology Research, v.2, p.48-51, 2012.

MARCOMINI, A. M. Bioatividade e efeito residual de nanoformulações de nim sobre Spodoptera frugiperda (J.E. Smith). 2009. 83f. Dissertação (Mestrado em Entomologia) Escola Superior de Agricultura Luiz de Queiroz. Piracicaba, SP.

MEDEIROS, P. T. et al. Instalação e manutenção de criação massal da traça-das-crucíferas (Plutella xylostella). Brasília: Embrapa Recursos Genéticos e Biotecnologia, 2003. 4p. (Embrapa Recursos Genéticos e Biotecnologia - Circular Técnica, 29).

NEVES, K. Nanotecnologia em cosméticos. Cosmetic \& Toiletries Brasil, v.20, n.1, p.22, 2008.

ONIMAWO, I. A. Proximate composition and selected physiochemical properties of the seed, pulp and oil of soursop (Annona muricata). Plant foods for human nutrition, v.57, n.2, p.165-171, 2002.

SAS Institute Inc. SAS ${ }^{\circledR}$ Satatical Analysis System, 2003.

SCHMALTZ, C. et al. Nanocápsulas como uma tendência promissora na área cosmética: a imensa potencialidade deste pequeno grande recurso. Infarma, v.16, n.13-14, p.80-85, 2005.

SHAHIDI, F.; HAN, X.Q. Encapsulation of food ingredients. Critical Review in Food Science and Nutrition, v.33, n.6, p.501547, 1993. Available from: <http://dx.doi.org/10.1021/bk-19950590.ch003>. Accessed: Oct. 30, 2015.

SILVA, F. A. S.; AZEVEDO, C. A. V. A. ASSISTAT, Assistência estatística. 2009. Versão 7,5 beta.

TALEKAR, N. S.; SHELTON, A. M. Biology, ecology, and management of the diamondback moth. Annual Review of Entomology, v.38, p.275-301, 1993.

TRINDADE, R. C. P. et al. Larvicidal activity and seasonal variation of Annona muricata (Anonaceae) extract on Plutella xylostella (Lepidoptera: Plutellidae). Revista Colombiana de Entomologia. v.37, p.223-227, 2011. 